University of Nebraska - Lincoln

DigitalCommons@University of Nebraska - Lincoln

Roman L. Hruska U.S. Meat Animal Research

U.S. Department of Agriculture: Agricultural Center

Research Service, Lincoln, Nebraska

2013

\title{
A simulation-based approach for evaluating and comparing the environmental footprints of beef production systems
}

C. A. Rotz

USDA/Agricultural Research Service

B. J. Isenberg

Pennsylvania State University

K. R. Stackhouse-Lawson

National Cattlemen's Beef Association

E. J. Pollak

USDA/Agricultural Research Service, jpollak2@unl.edu

Follow this and additional works at: https://digitalcommons.unl.edu/hruskareports

Rotz, C. A.; Isenberg, B. J.; Stackhouse-Lawson, K. R.; and Pollak, E. J., "A simulation-based approach for evaluating and comparing the environmental footprints of beef production systems" (2013). Roman $L$. Hruska U.S. Meat Animal Research Center. 263.

https://digitalcommons.unl.edu/hruskareports/263

This Article is brought to you for free and open access by the U.S. Department of Agriculture: Agricultural Research Service, Lincoln, Nebraska at DigitalCommons@University of Nebraska - Lincoln. It has been accepted for inclusion in Roman L. Hruska U.S. Meat Animal Research Center by an authorized administrator of DigitalCommons@University of Nebraska - Lincoln. 


\title{
A simulation-based approach for evaluating and comparing the environmental footprints of beef production systems ${ }^{1}$
}

\author{
C. A. Rotz, ${ }^{2}$ B. J. Isenberg, $†$ K. R. Stackhouse-Lawson, $\$$ and E. J. Pollak§ \\ *Pasture Systems and Watershed Management Research Unit, USDA/Agricultural Research Service, University Park, PA \\ 16802; †Pasture Systems and Watershed Management Research Unit, The Pennsylvania State University, University Park \\ 16802; \$National Cattlemen’s Beef Association, Centennial, CO 80112; §Roman L. Hruska U.S. Meat Animal Research \\ Center, USDA/Agricultural Research Service, Clay Center, NE 68933
}

\begin{abstract}
A methodology was developed and used to determine environmental footprints of beef cattle produced at the U.S. Meat Animal Research Center (MARC) in Clay Center, NE, with the goal of quantifying improvements achieved over the past $40 \mathrm{yr}$. Information for MARC operations was gathered and used to establish parameters representing their production system with the Integrated Farm System Model. The MARC farm, cow-calf, and feedlot operations were each simulated over recent historical weather to evaluate performance, environmental impact, and economics. The current farm operation included 841 ha of alfalfa and 1,160 ha of corn to produce feed predominately for the beef herd of 5,500 cows, 1,180 replacement cattle, and 3,724 cattle finished per year. Spring and fall cow-calf herds were fed on 9,713 ha of pastureland supplemented through the winter with hay and silage produced by the farm operation. Feedlot cattle were backgrounded for 3 mo on hay and silage with some grain and finished over 7 mo on a diet high in corn and wet distillers grain. For weather year 2011, simulated feed production and use, energy use, and production costs were within $1 \%$ of actual records. A
\end{abstract}

25-yr simulation of their current production system gave an average annual carbon footprint of $10.9 \pm$ $0.6 \mathrm{~kg}$ of $\mathrm{CO}_{2}$ equivalent units per $\mathrm{kg} \mathrm{BW}$ sold, and the energy required to produce that beef (energy footprint) was $26.5 \pm 4.5 \mathrm{MJ} / \mathrm{kg} \mathrm{BW}$. The annual water required (water footprint) was $21,300 \pm 5,600 \mathrm{~L} / \mathrm{kg} \mathrm{BW}$ sold, and the water footprint excluding precipitation was $2,790 \pm 910 \mathrm{~L} / \mathrm{kg}$ BW. The simulated annual cost of producing their beef was US $\$ 2.11 \pm 0.05 / \mathrm{kg} \mathrm{BW}$. Simulation of the production practices of 2005 indicated that the inclusion of distillers grain in animal diets has had a relatively small effect on environmental footprints except that reactive nitrogen loss has increased $10 \%$. Compared to 1970 , the carbon footprint of the beef produced has decreased $6 \%$ with no change in the energy footprint, a $3 \%$ reduction in the reactive nitrogen footprint, and a $6 \%$ reduction in the real cost of production. The water footprint, excluding precipitation, has increased $42 \%$ due to greater use of irrigated corn production. This proven methodology provides a means for developing the production data needed to support regional and national full life cycle assessments of the sustainability of beef.

Key words: beef production, carbon footprint, energy use, environment, nitrogen loss, water use

(C) 2013 American Society of Animal Science. All rights reserved.

This article is a U.S. government work, and is not subject to copyright in the United States.
J. Anim. Sci. 2013.91:5427-5437 doi:10.2527/jas2013-6506

\section{INTRODUCTION}

Beef is a major component of the U.S. food system with an average annual per capita consumption of $26 \mathrm{~kg}$ (USDA-ERS, 2012). To meet this demand, about 31 million breeding cows and bulls are maintained for the purpose of producing calves for beef production. Including calves from the dairy industry, there are about 27 million animals finished each year for slaughter and processing as retail beef. Along with

\footnotetext{
${ }^{1}$ Funded in part by The Beef Checkoff and the USDA's Agricultural Research Service. The authors thank Larry Cundiff, Chad Engle, Gordon Hays, Bucky Herman, and John Rieckman of the U.S. Meat Animal Research Center for providing current and historical information and data on the farm and cattle production practices of the Center. The USDA is an Equal Opportunity Employer.

${ }^{2}$ Corresponding author: al.rotz@ars.usda.gov

Received March 22, 2013.

Accepted August 14, 2013.
} 
cull cattle, the annual economic value of beef cattle produced in the United States is about 63 billion dollars.

As a major contributor to our food supply, beef production provides an important service to our economy. Production of cattle and associated feed crops also impact our environment, and this impact is not well understood. The Food and Agriculture Organization has reported that animal agriculture contributes $18 \%$ of global greenhouse gas emissions, greater than all transportation (Steinfeld et al., 2006). A national study has estimated that animal agriculture contributes 3.8\% of U.S. greenhouse gas emissions with transportation being about 6 times this amount (USEPA, 2012). A number of studies have determined a carbon footprint (net greenhouse gas emission) of beef production with most values ranging from 10 to $15 \mathrm{~kg} \mathrm{CO}$ equvilent $\left(\mathbf{C O}_{2} \mathbf{e}\right) / \mathrm{kg}$ BW (Beauchemin et al., 2010; Pelletier et al., 2010; Capper, 2011; Stackhouse-Lawson et al., 2012). Although the recent environmental focus has been on greenhouse gases, other impacts such as fossil energy use, water use, and reactive nitrogen loss must be considered.

Our objective was to develop and evaluate a methodology for using the Integrated Farm System Model (IFSM; USDA-ARS, University Park, PA) to quantify environmental footprints for current and historical beef cattle production. Specific objectives were to 1) evaluate the effectiveness of using IFSM to represent the current production system used at the Roman L. Hruska U.S. Meat Animal Research Center (MARC), 2) determine carbon, energy, water, and reactive nitrogen footprints of the beef produced with current production practices, and 3) quantify improvement by comparing current footprints to those determined using the production practices of MARC in 1970 and 2005.

\section{MATERIALS AND METHODS}

Animal Care and Use Committee approval was not obtained for this study because no animals were used.

The beef production system of MARC was modeled as 4 components: crop farm, spring-calving cowcalf operation, fall-calving cow-calf operation, and feedlot. Production and economic information for 2011 was used to set parameters in IFSM for each of the 4 components. The accuracy of the simulated system was evaluated by comparing predicted feed production and use, energy use, and production costs to actual records of MARC for 2011. Twenty-five year simulations were then performed to determine the long term carbon, energy, water, and reactive nitrogen footprints for the beef produced using current and historical practices. The year 1970 was selected to illustrate the production practices used $40 \mathrm{yr}$ ago and 2005 was used to capture the effect of including distillers grain in cattle diets.

\section{The Roman L. Hruska U.S. Meat Animal Research Center}

The MARC was established in 1966 in Clay Center, NE. It is a multispecies USDA-ARS facility where scientists work to develop information and new technology relevant to animal agriculture. Approximately $50 \%$ of the program is dedicated to beef cattle, which is the focus of this project, with the remainder being $30 \%$ swine and $20 \%$ sheep. The facility also produces the majority of the harvested forage and grain used by the livestock and this component is referred to as the farm operation. The MARC was selected for this analysis because of the extensive records available to support parameterization and evaluation of the model.

The land base of MARC is 12,150 ha. Of this total, 9,713 ha of grass pasture are used for grazing cattle with approximately 324 ha reseeded annually. The pasture mixes include perennial cool-season and warm-season species and annual triticale. In 2011, the farm operation of MARC planted 1,160 ha of corn, which were harvested as silage, high moisture corn (HMC), and dry corn grain. Corn silage was stored uncovered, on a cement pad, and HMC was covered in a bunker silo. Alfalfa was grown on 841 ha with approximately 168 ha reseeded each year. The crop was harvested as either hay, which was stored outside uncovered, or silage, which was stored in a covered bunker silo. Soybeans were planted on $63 \mathrm{ha}$; this crop was sold and thus was not used for beef production. The crop farm also produced feed for the other livestock (sheep and swine) maintained at MARC. Based on farm records, $82.5 \%$ of the feed produced and the production costs of the crop farm were designated to beef production. Additional crop management information is given in Table 1 .

About 5,498 cows and 285 bulls were maintained throughout 2011 to produce 5,050 calves. Mature maternal cow weight was $636 \mathrm{~kg}$, and mature bull weight was $908 \mathrm{~kg}$. Cows produced up to $10 \mathrm{~kg}$ of milk per day, and calves were weaned at 6 mo of age weighing about $296 \mathrm{~kg}$. Of these calves, 1,180 were raised as replacements to meet a $20 \%$ replacement rate for the cows and bulls. These cattle were managed in 10 groups with 7 groups using a spring calving cycle and the remainder using fall calving. Cows were maintained on rotationally grazed pasture using supplemental forage produced by the farming operation and small amounts of purchased feed to meet energy and mineral requirements (Table 2).

The feedlot operation contained 2 phases: backgrounding and finishing. After weaning, cattle were fed a high forage diet in the backgrounding phase for 3 mo 
Table 1. Farm crop area and management information for current (2011) production practices of the U.S. Meat Animal Research Center

\begin{tabular}{|c|c|c|c|c|c|c|}
\hline Crop & Area, ha & $\begin{array}{c}\text { Irrigated } \\
\text { area, ha }\end{array}$ & Crop use & $\begin{array}{l}\text { Yield, } \\
\text { t DM }\end{array}$ & Tillage method & Fertilization rate \\
\hline Grass & 9,606 & 947 & Grazed, 418 ha hay & $\mathrm{N} / \mathrm{A}^{1}$ & Strip till and field conditioner & $20 \mathrm{~kg} \mathrm{~N} / \mathrm{ha}$ \\
\hline Triticale & 107 & 197 & Grazed & N/A & No till & $20 \mathrm{~kg} \mathrm{~N} / \mathrm{ha}$ \\
\hline \multirow[t]{3}{*}{ Corn } & 1,160 & 1,160 & Silage & 7,627 & Strip till & $139 \mathrm{~kg} \mathrm{~N} / \mathrm{ha}$ \\
\hline & & & Dry grain & 3,723 & & \\
\hline & & & High moisture grain & 2,714 & & \\
\hline
\end{tabular}

${ }^{1} \mathrm{~N} / \mathrm{A}=$ not available.

(Table 2). In the 7 mo finishing phase, cattle were fed a high concentrate diet. Finished cattle were slaughtered at 16 mo of age weighing about $581 \mathrm{~kg}$. In 2011, MARC finished 3,724 cattle.

\section{The Integrated Farm System Model}

The IFSM is a research tool used to assess and compare the environmental and economic sustainability of farming systems. Crop production, feed use, and the return of manure nutrients back to the land are simulated for many years of weather on a crop, beef, or dairy farm (Rotz et al., 2012). Growth and development of crops are predicted for each day based on soil water and nitrogen availability, ambient temperature, and solar radiation. Simulated tillage, planting, harvest, storage, and feeding operations predict resource use, timeliness of operations, crop losses, and nutritive quality of feeds. Feed allocation and animal responses are related to the nutrient contents of available feeds and the nutrient requirements of the animal groups making up the herd. For beef operations, the animal groups can include cows, calves, replacement animals, stockers, and finishing cattle (Rotz et al., 2005). The quantity and nutrient contents of the manure produced are a function of the feeds consumed and herd characteristics.

Nutrient flows are tracked to predict losses to the environment and potential accumulation in the soil (Rotz et al., 2012). Environmental losses include ammonia emissions, denitrification and leaching losses of nitrogen, erosion of sediment across the farm boundaries, and the runoff of sediment-bound and dissolved phosphorus. The sum of the various forms of nitrogen loss provides a total reactive nitrogen loss. Carbon dioxide, methane, and nitrous oxide emissions are tracked from crop, animal, and manure sources and sinks to predict net greenhouse gas emission. Whole-farm mass balances of nitrogen, phosphorus, potassium, and carbon are determined as the sum of nutrient imports in feed, fertilizer, deposition, and fixation minus the nutrient exports in milk, excess feed, animals, manure, and losses leaving the operation.

Simulation of a production system provides the direct emissions and resources used each year. A cradle-tofarm gate partial life cycle assessment (LCA; Rotz et al., 2010) is done to determine annual carbon, energy, water, and reactive nitrogen footprints. These represent the net greenhouse gas emission, fossil energy use, water use, and reactive nitrogen loss, respectively. The LCA also includes pre-chain sources, which are those that occur during the production of resources used on the farm. Important resources are fuel, natural gas, electricity, fertilizer, purchased feed, machinery, seed, and pesticides. The total of direct and pre-chain sources divided by the amount of feed, milk, or animal BW produced provides the footprint.

Simulated performance is used to determine production costs, incomes, and economic return for each year of weather. A whole-farm budget includes fixed and variable production costs (Rotz et al., 2012). All important production costs are subtracted from the total income received for animal and excess feed sales to determine a net return to management. By comparing simulation results, differences among production systems are determined, including annual resource use, production efficiency, environ-

Table 2. Cattle numbers, annual feed use, and typical diets for animal groups maintained at the U.S. Meat Animal Research Center in 2011

\begin{tabular}{lccc}
\hline \hline Cattle type & Total number & Annual feed use, t DM & Typical diets, \% DM \\
\hline Cow-calf & & & \\
$\quad$ Spring calving & 4,312 & 4,756 & Pasture plus hay (83\%) and corn silage (15\%) \\
Fall calving & 1,471 & 2,708 & High moisture corn (2\%) \\
Feedlot & & & \\
Backgrounding & 3,742 & 1,903 & Hay (15\%), corn silage (71\%) and distillers grain (14\%) \\
$\quad$ Finishing & 3,724 & 7,157 & Corn silage (20\%), dry corn (29\%) and distillers grain (51\%) \\
\hline
\end{tabular}


mental impacts, production costs, and farm profit. Simulations are conducted over a 25-yr sample of historical weather, so the resulting distribution of annual predictions represents the effects of varying weather.

For this study, a few changes were made to improve the model or to better represent the MARC production system. The major change was a reduction in the simulated enteric methane emissions. The relationship used to predict enteric emissions was developed by Mills et al. (2003) for dairy cattle (Rotz et al., 2012). Based on a previous comparison of simulated and measured emissions (Stackhouse-Lawson et al., 2012), the maximum potential methane production parameter of the Mills equation was reduced from 45.98 to $36.8 \mathrm{MJ} \mathrm{CH}_{4} / \mathrm{d}$ per cow. This reduced methane production of cattle on high forage diets by $20 \%$. To match the cattle at MARC, the twin rate was set at $2 \%$ and calf mortality rate was set at $10 \%$. A new parameter was added to account for electricity use in supplying drinking water to pasture. This annual electrical use was set at $425 \mathrm{kWh}$ per watering unit with 1 unit servicing 16 ha of pasture. An electrical use of $3.3 \mathrm{kWh} / \mathrm{mo}$ per animal was added for the feedlot to account for all electricity use beyond that used for lighting. Electricity use for feedlot lighting was $5 \mathrm{kWh} /$ mo per animal. All other model functions and fixed parameters were as described by Rotz et al. (2012).

\section{Model Calibration and Evaluation}

The farm, 2 cow-calf, and feedlot operations were each simulated for 2011 using daily weather data from Hastings, NE (about $24 \mathrm{~km}$ from MARC). Simulated production of alfalfa hay, corn silage, HMC, dry corn grain, and soybeans were compared to farm records for 2011 along with purchased corn and distillers grain. Simulated energy use of fuel, natural gas, and electricity were also compared to farm records. For further verification, the major production costs of fertilizer, seed and herbicide, energy, labor, purchased feed, veterinary and medicine, implant and ionophore treatments, and breeding were compared to actual records.

Along with the model refinements described above, some further adjustment of model parameters was required to obtain close comparisons between simulated and reported data. These adjustments included refinement of crop parameters and the resulting yields, type, size, and power requirements of machinery, nutrient contents of feeds, and prices of resource inputs. Prices were set to those incurred in 2011 for purchased feeds, fuel, fertilizer, etc. For equipment and facilities, current prices were assumed and fixed costs were determined by amortizing the initial cost over 14 yr for machinery and $30 \mathrm{yr}$ for structures. These refinements were made through extensive communication with the managers of the MARC operations. A comparison of simulated and reported values for this year assured that the model adequately represented the current performance of the MARC production system.

A sensitivity analysis was done to determine how various factors affected the predicted carbon and energy footprints. Because of the large number of parameters used to predict these outputs, sensitivity to individual parameters was not practical. Instead, the sensitivity was determined for the direct carbon components of $\mathrm{CH}_{4}$, $\mathrm{N}_{2} \mathrm{O}$, and $\mathrm{CO}_{2}$ emissions and the direct energy inputs for feed production, animal feeding, manure handling, and all other electrical use. Sensitivity was also determined for the pre-chain sources producing fuel, electricity, machinery, fertilizer, seed, chemicals, and distillers grain. A sensitivity index was determined for each where the index was the ratio of the change in output (carbon or energy footprint) to a $10 \%$ change in the component. A sensitivity index greater than 0.6 indicated high sensitivity, a value between 0.1 and 0.6 indicated moderate sensitivity, and a value less than 0.1 indicated low sensitivity.

\section{Analysis of Current Production System}

After the evaluation of the model, each of the 4 component operations was simulated for $25 \mathrm{yr}$ using weather data for Grand Island, NE (about $56 \mathrm{~km}$ from MARC because long term data were not available from Hastings). The independent simulation of each component operation produced the net greenhouse gas emission, energy use, water use, reactive nitrogen loss, and production costs for that part of the overall operation. Because the farm produced feed for other livestock, only $82.5 \%$ of the emissions and costs associated with the farm operation were included in the total. Dividing the total by the body weight of the beef produced (including all finished cattle, cull cows, and cull bulls) provided footprints for the full production system.

Direct sources of greenhouse gas predicted by IFSM were $\mathrm{CH}_{4}$ from enteric fermentation and manure handling, $\mathrm{N}_{2} \mathrm{O}$ from the soil and manure handling, and $\mathrm{CO}_{2}$ from the combustion of fossil fuels. For MARC simulations, net $\mathrm{CO}_{2}$ emission was reduced by the amount of $\mathrm{CO}_{2}$ assimilated in feed that ultimately created the $\mathrm{CH}_{4}$ emitted. Pre-chain sources from resources used to produce beef cattle at MARC and their associated emission factors are given in Table 3. Production of distillers grain is an important pre-chain source when evaluating changes through time. Conservative estimates for pre-chain sources of distillers grain were used where factors were set equal to that of the feeds (corn and urea) replaced along with minor energy use for transport (Table 3). Previous studies have documented a carbon footprint of $1 \mathrm{~kg} \mathrm{CO} 2 \mathrm{e} / \mathrm{kg} \mathrm{DM}$ using 
Table 3. Emission factors used in the life cycle assessment to represent pre-chain emissions occurring during the production of resources used in producing beef cattle at the U.S. Meat Animal Research Center

\begin{tabular}{|c|c|c|c|}
\hline $\begin{array}{l}\text { Emission } \\
\text { source }\end{array}$ & $\begin{array}{c}\text { Greenhouse gas } \\
\text { emissions, } \mathrm{kg} \mathrm{CO}_{2} \mathrm{e}^{1}\end{array}$ & $\begin{array}{l}\text { Energy use, } \\
\text { MJ }\end{array}$ & Source \\
\hline \multicolumn{4}{|l|}{ Energy sources } \\
\hline Fuel & $0.522 / \mathrm{L}$ & $4.01 / \mathrm{L}$ & $\mathrm{BASF}^{2}$ \\
\hline Natural gas & $0.668 / \mathrm{m}^{3}$ & $2.46 / \mathrm{m}^{3}$ & BASF \\
\hline Electricity & $0.629 / \mathrm{kWh}$ & $5.00 / \mathrm{kWh}$ & BASF \\
\hline \multicolumn{4}{|l|}{ Fertilizer } \\
\hline Nitrogen & $3.11 / \mathrm{kg} \mathrm{N}$ & $62.4 / \mathrm{kg} \mathrm{N}$ & BASF \\
\hline Phosphate & $1.84 / \mathrm{kg} \mathrm{P}_{2} \mathrm{O}_{5}$ & $32.5 / \mathrm{kg} \mathrm{P}_{2} \mathrm{O}_{5}$ & BASF \\
\hline Potash & $1.30 / \mathrm{kg} \mathrm{K}_{2} \mathrm{O}$ & $18.4 / \mathrm{kg} \mathrm{K}_{2} \mathrm{O}$ & BASF \\
\hline \multicolumn{4}{|l|}{ Purchased feed } \\
\hline Corn & $0.34 / \mathrm{kg}$ & $3.00 / \mathrm{kg}$ & $\mathrm{IFSM}^{3}$ \\
\hline Forage & $0.16 / \mathrm{kg}$ & $1.56 / \mathrm{kg}$ & IFSM \\
\hline Urea & $1.43 / \mathrm{kg}$ & $25.2 / \mathrm{kg}$ & BASF \\
\hline Wet distillers grain & $0.41 / \mathrm{kg}$ & $3.80 / \mathrm{kg}$ & IFSM \\
\hline \multicolumn{4}{|c|}{ Machinery manufacture $3.54 / \mathrm{kg}$ machine mass $42.6 / \mathrm{kg}$ machine mass GREET $^{4}$} \\
\hline Seed & $0.3 / \mathrm{kg}$ & $85.0 / \mathrm{kg}$ & IFSM \\
\hline Pesticide & $22.0 / \mathrm{kg}$ a.i. ${ }^{5}$ & $275 / \mathrm{kg}$ a.i & GREET \\
\hline \multicolumn{4}{|c|}{${ }^{1} \mathrm{CO}_{2} \mathrm{e}=\mathrm{CO}_{2}$ equivelant units. } \\
\hline \multicolumn{4}{|c|}{${ }^{2}$ Obtained from BASF's Eco-efficiency analysis tool (Saling et al., 2002). } \\
\hline \multicolumn{4}{|c|}{$\begin{array}{l}{ }^{3} \text { Derived through simulations of various production systems with the Inte- } \\
\text { grated Farm System Model (IFSM; Rotz et al., 2012). }\end{array}$} \\
\hline \multicolumn{4}{|c|}{${ }^{4}$ Obtained from the Greenhouse Gases, Regulated Emissions, and Energy } \\
\hline \multicolumn{4}{|c|}{ Use in Transportation (GREET) model (Wang, 2012). } \\
\hline \multicolumn{4}{|c|}{5 a.i. $=$ active ingredient. } \\
\hline
\end{tabular}

an economic allocation of coproducts after distillation (Thoma et al., 2011). This value is relatively high compared to that of corn production (Table 3 ) due primarily to the large amount of energy used in the process of creating alcohol. This high value, along with undocumented values for other environmental footprints, led to our more conservative approach.

In IFSM, daily $\mathrm{N}_{2} \mathrm{O}$ emissions are a function of soil texture, nitrogen content, temperature, and moisture content (Rotz et al., 2012). The soil $\mathrm{N}_{2} \mathrm{O}$ emissions included in our analysis were the difference between that predicted for the full system with fertilizer and manure application to the soil and that without any added nitrogen. This approach represented that of the International Panel on Climate Change (IPCC, 2006) where the included $\mathrm{N}_{2} \mathrm{O}$ emissions are those from the nitrogen applied to the soil. To establish a baseline, which essentially represented natural prairie, the grazing operations were simulated with IFSM without animals and any use of nitrogen fertilizer. This baseline of $0.67 \mathrm{~kg} \mathrm{~N}_{2} \mathrm{O} /$ ha was subtracted from the simulated predictions with animals and fertilizer use to obtain the $\mathrm{N}_{2} \mathrm{O}$ emissions attributed to the crop and animal production system of MARC.
Table 4. Cattle populations for 1970, 2005, and 2011 to maintain the same amount of total beef produced at the U.S. Meat Animal Research Center

\begin{tabular}{lrrr}
\hline \hline Cattle type & 1970 & 2005 & 2011 \\
\hline Spring cows and bulls & 5,131 & 4,444 & 4,312 \\
Fall cows and bulls & 1,750 & 1,516 & 1,471 \\
Replacements & 1,450 & 1,216 & 1,180 \\
Finished cattle & 4,434 & 3,838 & 3,724 \\
Finished BW, kg & 488 & 564 & 581 \\
\hline
\end{tabular}

\section{Historical Production Systems}

To determine changes in the environmental footprints through time, MARC production systems used in 2005 and 1970 were simulated. These historical simulations were completed with the stipulation of maintaining the same total beef production as that produced in 2011. In comparison to 2011, animals in both 1970 and 2005 were smaller (Professional Cattle Consultants, Hydro, OK, personal communication), so animal numbers were increased to maintain the same total beef produced (Table 4).

The year 2005 was selected because MARC did not include distillers grain in cattle diets up to that date. After 2005, distillers grain became a major component of backgrounding and finishing cattle diets. The farm operation did not produce soybeans in 2005, so the 63 ha used to produce soybeans in 2011 was transferred to corn land. To reflect genetic improvement in corn yield over this $6 \mathrm{yr}$ period, the corn grain yield was reduced $6 \%$. This reduction factor was obtained through a linear regression of irrigated corn grain yield for this region (NASS, 2012) across years from 1970 to 2011. This regression provided the change in yield over each period with variable weather effects removed. Corn silage yield was not changed (NASS, 2012).

Based on representative industry data (Professional Cattle Consultants, Hydro, OK, personal communication), mature cow weight was reduced to $617 \mathrm{~kg}$ in 2005. Calves were weaned at $293 \mathrm{~kg}$, and cattle were finished at $563 \mathrm{~kg}$. To produce the same quantity of beef, cow and bull numbers were increased to 5,960, replacements were increased to 1,216 , and 3,838 animals were finished. Distillers grain was removed from cattle diets and replaced with corn and a small amount of urea as required to meet animal energy and protein requirements (Rotz et al., 2005). All other model parameters were the same as those assigned for 2011 simulations.

The year 1970 was selected to evaluate changes that have taken place at MARC over the past $40 \mathrm{yr}$ and to determine how these changes have affected the environmental footprints and costs of beef production. Model parameters assigned to represent the 1970 production system were established through various sources of historical information. Important changes included crop 
Table 5. A comparison of actual and simulated feed production in the farming operation and feed use in the cow-calf and feedlot operations of the U.S. Meat Animal Research Center in 2011

\begin{tabular}{|c|c|c|c|c|c|c|c|}
\hline \multirow[b]{2}{*}{ Feed type } & \multicolumn{2}{|c|}{ Farm production, t DM } & \multicolumn{2}{|c|}{ Cow-calf use, t DM } & \multicolumn{2}{|c|}{ Feedlot use, t DM } & \multirow{2}{*}{$\begin{array}{c}\text { Difference, } \\
\%\end{array}$} \\
\hline & Actual & Simulated & Actual & Simulated & Actual & Simulated & \\
\hline Pasture & 0 & 0 & $-{ }^{1}$ & 23,808 & 0 & 0 & - \\
\hline Corn silage & 7,627 & 7,635 & 2,428 & 2,416 & 2,515 & 2,507 & -0.1 \\
\hline High moisture corn & 2,714 & 2,718 & 105 & 104 & 2,702 & 2,718 & 0.3 \\
\hline Corn grain & 3,723 & 3,751 & 56 & 56 & 1,608 & 1,596 & 0.3 \\
\hline Total DM & 22,948 & 23,067 & 7,464 & 7,456 & 9,159 & 9,152 & 0.3 \\
\hline
\end{tabular}

${ }^{1}$ Actual pasture DM intake was not known.

areas, tillage and harvest practices, machinery size, and animal size. No price changes were made to maintain all production cost predictions in current dollars.

The land area, irrigation, and fertilization of the alfalfa crop remained the same in 1970 as assigned in 2011. Alfalfa was established using a moldboard plow and 2 disking operations. Corn land was reduced to 567 ha because in 1970 only corn silage was produced and corn grain was purchased (Larry Cundiff, personal communication). Corn was planted after 2 disking operations, and $75 \%$ of the available manure was applied to corn land. Data from the USDA Economic Research Service (USDA-ERS, 2011) indicated that little change in fertilizer use has occurred in this region over the past $40 \mathrm{yr}$, so fertilization rates remained the same as in 2011. Due to the reduction in corn land, though, less fertilizer and irrigation were used. To account for genetic improvement in crop yields, the average yield of alfalfa, corn silage, and corn grain were reduced by 12,20 , and $26 \%$ respectively using the linear regression procedure described for 2005 .

The 656 ha removed from corn and soybean production were shifted to grass hay production. Grass fields were moldboard plowed, disked, and seeded with bromegrass. The grass received $56 \mathrm{~kg} \mathrm{~N} / \mathrm{ha}$ of fertilizer and $20 \%$ of the available manure. Two cuttings were harvested: one in early summer and one in late summer. The grass hay and alfalfa were harvested with stack forming machines, the technology used at that time (Larry Cundiff, personal communication). As in 2005, no soybeans were produced. To represent the smaller equipment used in 1970, all field machinery were reduced in size by about $50 \%$, and the number of machines was increased as needed to complete farm operations. Except for the larger tractors, machinery operations used gasoline instead of the diesel fuel used in recent years.

To represent the cattle of 1970, mature cow size was reduced $19 \%(533 \mathrm{~kg})$ with a maximum milk production of $6.8 \mathrm{~kg} / \mathrm{day}$, and calves were weaned at 7 mo of age with no change in calving rate or replacement rate of the breeding stock (Cundiff et al., 1984). Total cow and bull numbers were increased $19 \%$ to 6,881 with 1,450 replace- ments. The cows were fed bromegrass hay as a supplement in the winter and did not receive corn silage. The pastures were not irrigated or fertilized. Only a spring calving cycle was used (Larry Cundiff, personal communication). Weaned cattle entered the backgrounding stage at $287 \mathrm{~kg}$ and were slaughtered at $488 \mathrm{~kg}$ (Professional Cattle Consultants, Hydro, OK, personal communication). On the feedlot, cattle received a backgrounding diet (75\% forage and $25 \%$ corn grain) for 3 mo and a finishing diet (60\% forage and $40 \%$ corn grain) for 6 mo (Smith et al., 1976). The number of cattle entering the feedlot was increased to 4,453; after mortalities, 4,434 were finished.

\section{RESULTS AND DISCUSSION}

\section{Model Calibration and Evaluation}

Simulated values for feed production and use and energy use were compared to reported records for 2011 to evaluate model performance in representing MARC. This particular year had above average rainfall, which produced greater crop yields with less irrigation than most years. Simulating over these local weather conditions, the model was able to represent feed production and use within $1 \%$ of reported numbers (Table 5), well within the accuracy of the reported values. For energy use, the model predicted annual use of fuel, natural gas, and electricity within $1 \%$ of recorded values (Table 6). For further evaluation, the model predicted major production costs for 2011 also within $1 \%$ of reported values (Table 7). These data support that the model was well calibrated to represent the production system of MARC.

Because environmental data were not available for the MARC production system, this aspect of the model could not be evaluated for their operation. Previous analyses have shown that the model can represent important emissions when production systems are appropriately modeled (Rotz et al., 2006, 2010; Stackhouse-Lawson et al., 2012). Therefore, the accuracy of representing the performance of the production system along with previous model evaluations support that the model properly 
Table 6. Actual and simulated energy use at the U.S. Meat Animal Research Center in 2011

\begin{tabular}{lcrrc}
\hline \hline Energy source & Unit & Actual & Simulated & Difference, $\%$ \\
\hline Fuel & $\mathrm{L}$ & 462,900 & 458,700 & -0.9 \\
Natural Gas & $\mathrm{m} 3$ & 286,200 & 287,011 & 0.3 \\
Electricity & $\mathrm{kWh}$ & $1,070,441$ & $1,070,880$ & 0.0 \\
\hline
\end{tabular}

represented environmental emissions and the calculated footprints. Energy use is an important part of the energy and carbon footprints, and this particular aspect was shown above to be accurately represented by the model.

\section{Current Production System}

The environmental footprints determined for the beef produced at MARC using current production practices are given in Table 8 . The average carbon footprint of the animal live weight leaving the operation was $10.9 \mathrm{~kg} \mathrm{CO}_{2} \mathrm{e} /$ $\mathrm{kg} \mathrm{BW}$ with $95 \%$ of the annual values between $\pm 0.6 \mathrm{~kg}$ $\mathrm{CO}_{2} \mathrm{e} / \mathrm{kg} \mathrm{BW}$. Of this net emission of greenhouse gases, $71 \%$ occurred in the cow-calf portion of the production system. Over half of the total footprint was from methane emissions with most of these emissions coming from enteric fermentation (Fig. 1). Although this value was somewhat lower than previous studies, it was comparable. Johnson et al. (2003) reported a carbon footprint of 11.0 to $13.0 \mathrm{~kg} \mathrm{CO} 2 \mathrm{e} / \mathrm{kg} \mathrm{BW}$ for U.S. beef. Additional studies by Pelletier et al. (2010), Capper (2011), and StackhouseLawson et al. (2012) reported values of 14.8 to 19.2, 10.4, and 12.7 to $14.5 \mathrm{~kg} \mathrm{CO}_{2} \mathrm{e} / \mathrm{kg} \mathrm{BW}$ for Midwest, United States, and California beef production, respectively. Carbon footprints reported for Canadian beef production were $13.6 \mathrm{~kg} \mathrm{CO}_{2} \mathrm{e} / \mathrm{kg} \mathrm{BW}$ (Beauchemin et al., 2010) and 9.7 to $11.5 \mathrm{~kg} \mathrm{CO}_{2} \mathrm{e} / \mathrm{kg} \mathrm{BW}$ (Vergé et al., 2008).

The carbon footprint of the cattle produced at MARC was not highly sensitive to any of the emission sources (Fig. 2). There was moderate sensitivity to direct $\mathrm{CH}_{4}$ and $\mathrm{N}_{2} \mathrm{O}$ emission sources with low sensitivity to $\mathrm{CO}_{2}$ sources and all pre-chain sources. These data indicate that if substantial reductions in carbon emissions are to be made for beef cattle produced at $\mathrm{MARC}, \mathrm{CH}_{4}$, and particularly enteric $\mathrm{CH}_{4}$, reductions must be made. Reduction in $\mathrm{N}_{2} \mathrm{O}$ emissions is also important, but reductions in all other sources would have little impact.
Table 7. Actual and simulated production costs for beef production at the U.S. Meat Animal Research Center in 2011

\begin{tabular}{lrcc}
\hline \hline Category & Actual, $\$$ & Simulated, $\$$ & Difference, $\%$ \\
\hline Seed and herbicide & 285,300 & 285,344 & 0.0 \\
Fertilizer & 483,700 & 485,984 & 0.5 \\
Fuel & 392,282 & 391,448 & -0.2 \\
Natural gas & 67,400 & 67,569 & 0.3 \\
Electricity & 53,500 & 53,544 & 0.1 \\
Labor & $2,220,000$ & $2,218,851$ & -0.1 \\
Purchased feed & 566,000 & 564,328 & -0.3 \\
Vet and medicine & 80,000 & 80,496 & 0.6 \\
Implant and ionophore & 7,600 & 7,671 & 0.9 \\
Breeding & 60,000 & 60,028 & 0.0 \\
Other miscellaneous & 100,000 & 99,921 & -0.1 \\
Total & $4,315,782$ & $4,315,184$ & 0.0 \\
\hline
\end{tabular}

The annual energy footprint of beef produced at MARC was $27.0 \pm 4.5 \mathrm{MJ} / \mathrm{kg} \mathrm{BW}$ with about half of this energy used in the farm operation (Table 8). Of the total footprint, about half was from pre-chain energy use, that is, the energy used to produce fertilizer, fuel, electricity, and other resources used in the production system. Few studies have reported energy footprints for beef production. The footprint determined by IFSM was lower than the $44.8 \mathrm{MJ} / \mathrm{kg} \mathrm{BW}$ reported by Pelletier et al. (2010) for a similar beef production system in the upper midwestern United States. In a French suckler-beef system, the energy footprint was reported as 58 to $67 \mathrm{MJ} /$ kg BW (Veysset et al., 2010). Capper (2011) reported a fossil fuel energy input of $9.6 \mathrm{MJ} / \mathrm{kg}$ of beef produced in the United States. Caution is needed when comparing values obtained from different LCA because each study used different system boundaries and assumptions, particularly those related to pre-chain inputs. Because these boundaries and assumptions were not clearly defined in the previous studies, causes for these large differences cannot be determined.

The energy footprint of the beef produced at MARC was moderately sensitive to the fuel used in feed production and the energy used to produce $\mathrm{N}$ fertilizer. Although all other pre-chain energy inputs showed relatively low sensitivity, when summed together, they do have a moderate impact. To reduce the energy footprint of producing these cattle, emphasis should be placed on

Table 8. Environmental footprints (per kg BW) of beef produced at the U.S. Meat Animal Research Center using current production practices

\begin{tabular}{|c|c|c|c|c|c|c|c|c|c|c|}
\hline \multirow[b]{2}{*}{ Operation } & \multicolumn{2}{|c|}{ Carbon } & \multicolumn{2}{|c|}{ Energy } & \multicolumn{2}{|c|}{ Water } & \multicolumn{2}{|c|}{ Water without precipitation } & \multicolumn{2}{|c|}{ Reactive N } \\
\hline & $\mathrm{kgCO}_{2} \mathrm{e}^{1}$ & $\%$ & MJ & $\%$ & $\bar{L}$ & $\%$ & $\mathrm{~L}$ & $\%$ & $\mathrm{~g} \mathrm{~N}$ & $\%$ \\
\hline Crop farm & 1.09 & 10 & 12.2 & 45 & 4,469 & 21 & 1,796 & 64 & 5.8 & 6 \\
\hline Cow-calf & 7.79 & 71 & 10.5 & 39 & 16,320 & 76 & 766 & 28 & 55.7 & 61 \\
\hline Feedlot & 2.03 & 19 & 4.2 & 16 & 551 & 3 & 227 & 8 & 30.1 & 33 \\
\hline Total & 10.92 & - & 27.0 & - & 21,340 & - & 2,789 & - & 91.7 & - \\
\hline
\end{tabular}




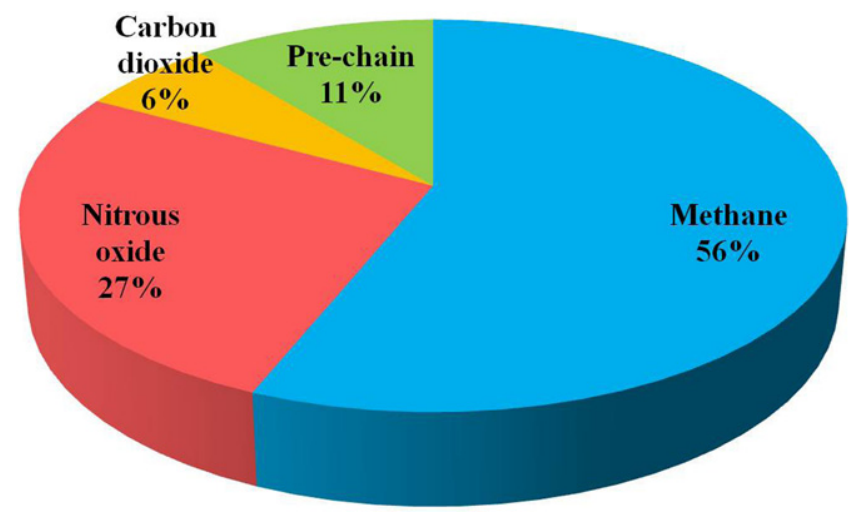

Figure 1. Emission sources contributing to the carbon footprint of beef produced at the U.S. Meat Animal Research Center using 2011 production practices. See online version for figure in color.

reducing fuel consumption in feed production and feeding. Secondarily, improving the energy efficiency in producing the various resource inputs is important.

The annual water footprint determined for the MARC production system, excluding that obtained through precipitation, was $2,789 \pm 914 \mathrm{~L} / \mathrm{kg}$ BW (Table 8). Including precipitation, the water footprint was $21,340 \pm 5,600$ $\mathrm{L} / \mathrm{kg} \mathrm{BW}$. When precipitation was included, $76 \%$ of the water footprint was associated with the cow-calf operation; without precipitation, the major portion of the water was used in the farm operation. In either case, nearly all of the water was used for feed production with drinking water making up $1 \%$ or less of the water footprint.

The various assumptions made and units used in other studies make it difficult to compare values. Beckett

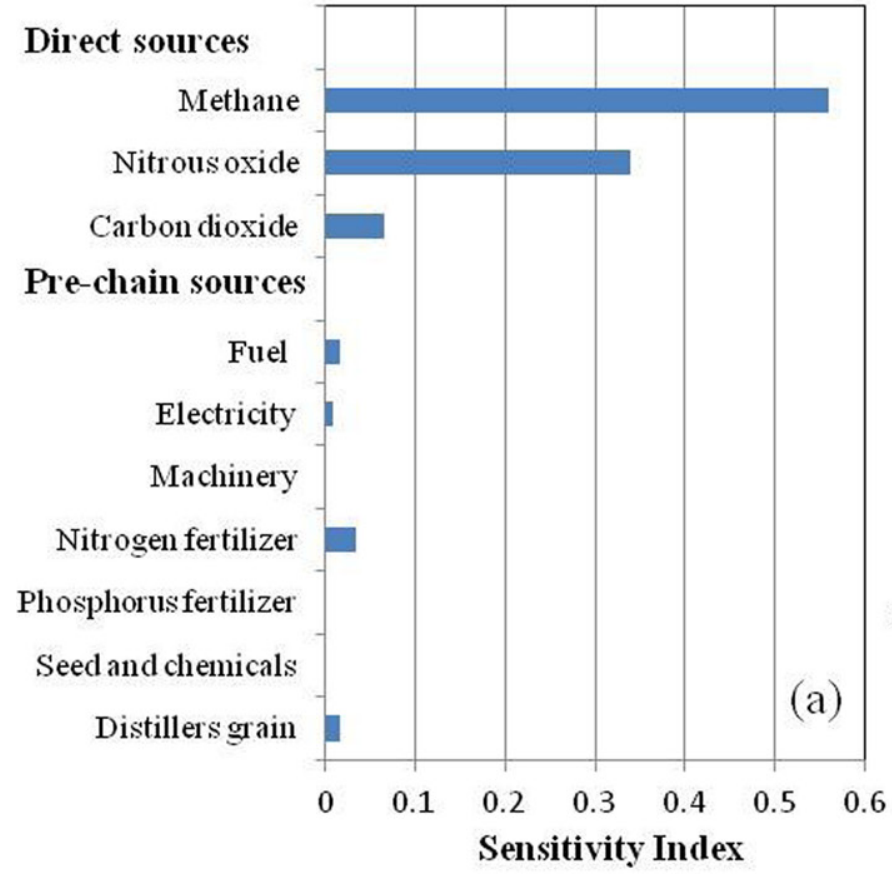

and Oltjen (1993) reported a water footprint of 17,800 L/ $\mathrm{kg}$ of boneless beef, and Mekonnen and Hoekstra (2010) reported a value of $64,200 \mathrm{~L} / \mathrm{kg} \mathrm{BW}$ as a global average. In a study by Ridoutt et al. (2011), Australian beef had a water footprint in the range of 15.8 to $1,067 \mathrm{~L} / \mathrm{kg} \mathrm{BW}$. The major factor causing this very wide range in reported values is the type of water included in the calculation. As illustrated by the 2 values given for MARC, the major issue is whether precipitation is included. Precipitation is an important and major contributor to the water used to produce feed. This precipitation would fall on the land whether it is used to produce cattle feed or not, so there is justification for leaving it out of the footprint. Because irrigation is heavily used at MARC, the water footprint without precipitation should be greater than that for most beef production systems. The use of irrigation has little effect on the total water footprint, though, because the moisture required to produce crops is largely independent of source.

The annual reactive nitrogen footprint of beef produced at MARC was $91.7 \pm 18.4 \mathrm{~g} \mathrm{~N} / \mathrm{kg}$ BW. No other known studies have determined a reactive $\mathrm{N}$ footprint, so this value could not be compared to other studies. Most of the footprint was associated with cattle on pasture (61\%) in the cow-calf operations (Table 8). Ammonia emissions contributed $81 \%$ of the footprint with nitrate leaching and nitrous oxide emissions contributing 6 and $9 \%$, respectively.

The annual cost of producing beef at MARC using current production practices was $\$ 2.11 \pm 0.05 / \mathrm{kg}$ BW. The largest portion of this cost was for labor (34\%) with

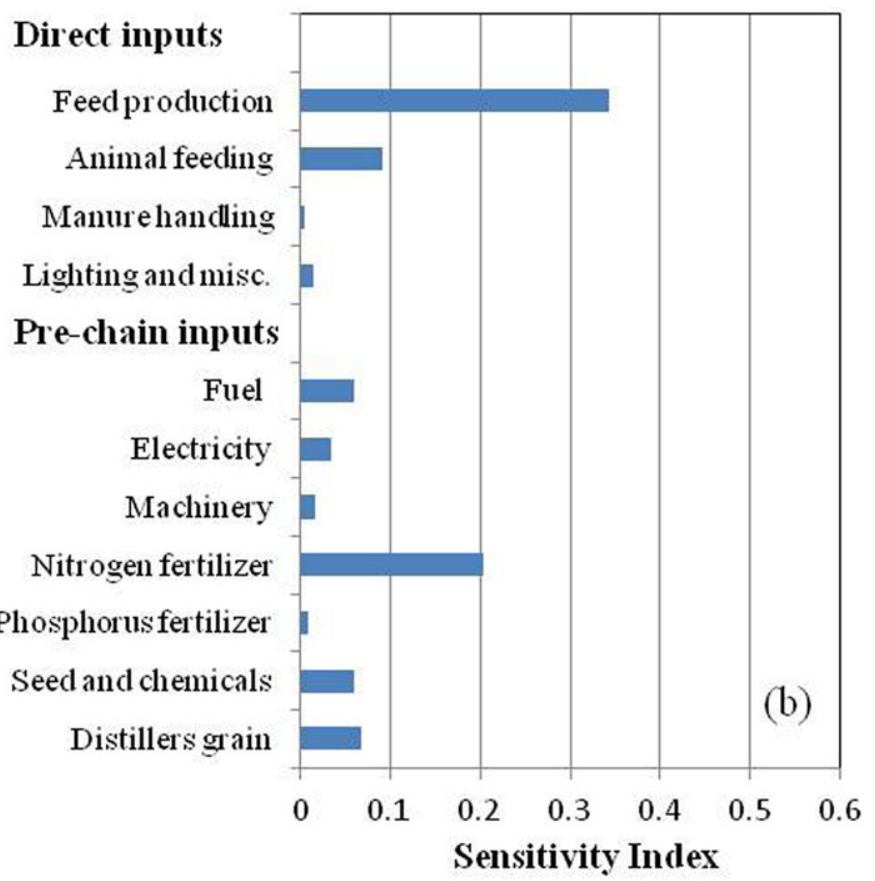

Figure 2. Sensitivity of the carbon footprint (a) and energy footprint (b) of beef cattle production at the U.S. Meat Animal Research Center to direct and pre-chain sources. A sensitivity index less than 0.1 indicates relatively low sensitivity to a change in value and values of 0.1 to 0.6 indicate moderate sensitivity. See online version for figure in color. 
the second largest portion being the costs of owning and maintaining equipment (26\%; Fig. 3). Because MARC is a government research facility, their costs of production are expected to be greater than most private operations. In particular, the labor required and wage rate are likely high. In our analysis, though, the costs and practices associated with research were not included to the extent possible.

\section{Historical Production Systems}

Simulation of the production practices of 2005 and 1970 were used to determine changes in the environmental footprints through time. After 2005, distillers grain was used in place of a portion of the corn in cattle diets. Other changes such as replacing soybeans with additional corn had no effect on the environmental footprints of beef, and the small decrease in corn yield reflecting genetic improvement since 2005 increased the footprints about $1 \%$ (data not shown). Compared to 2011, the carbon and energy footprints of 2005 were just slightly less (Table 9). This implies that the feeding of distillers grain has increased these life cycle environmental impacts of beef production, offsetting the small improvement obtained through genetic improvement of corn yield.

Our assumption that the footprints of distillers grain were equal to that of the purchased corn and urea feeds replaced may be considered conservative. In an evaluation of the carbon footprint of pork production, the carbon footprint used for dry distillers grain was $1 \mathrm{~kg} \mathrm{CO}_{2} \mathrm{e} / \mathrm{kg} \mathrm{DM}$ (Thoma et al., 2011). Using this value would increase the carbon footprint of the beef produced in 2011 to $11.2 \mathrm{~kg}$ $\mathrm{CO}_{2} \mathrm{e} / \mathrm{kg} \mathrm{BW}$, a 3.4\% increase over the footprint in 2005 .

Water footprints were very similar between 2011 and 2005 whether precipitation was included or not (Table 9). With the minor management changes made over this period, little change was expected. Because the water footprint of distillers grain was set equal to that of the feeds replaced, replacing corn and urea with distillers grain had little effect.

The reactive nitrogen footprint increased about $10 \%$ from 2005 to 2011 (Table 9). With the feeding of distillers grain, there was overfeeding of protein. This excess feed protein led to a greater excretion of nitrogen, pri-

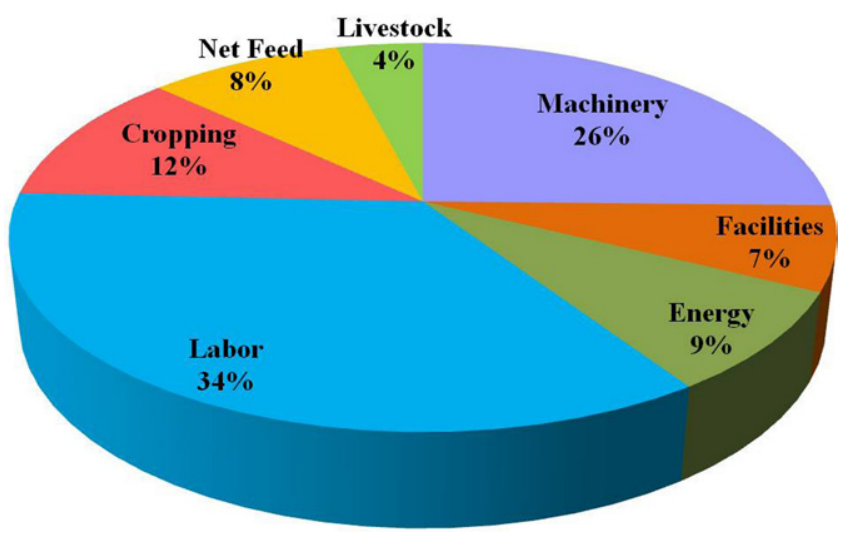

Figure 3. Production cost distribution for the beef produced at the U.S. Meat Animal Research Center using 2011 production practices. See online version for figure in color.

marily as urea in urine. This urea transformed to ammonia, which volatilized from the feedlot surface increasing the amount of reactive nitrogen lost to the environment.

The environmental footprints of the 1970 beef production system reflect the effects of the numerous changes that have occurred over the past $40 \mathrm{yr}$. The carbon footprint for 1970 was $11.6 \mathrm{~kg} \mathrm{CO}_{2} \mathrm{e} / \mathrm{kg} \mathrm{BW}$ indicating a $6 \%$ improvement for the 2011 beef production system. Capper (2011) determined a 16\% improvement in the carbon footprint of the U.S. beef industry from 1977 to 2007. To represent changes in the industry, Capper assumed that $12.9 \%$ of the cattle came from dairy calves in 2007 with no dairy calves used in 1977. When dairy calves are finished for beef, a major portion of the footprint of the breeding stock is attributed to dairy production. Because about $70 \%$ of the carbon footprint of beef cattle breeds is from the cow-calf phase, removing this phase for a portion of the cattle creates a substantial reduction in the total footprint. Because the MARC production system includes only traditional beef breeds, this benefit of using dairy calves was not obtained. When a simulation analysis was done that included the use of dairy calves (data not shown), a $14 \%$ reduction in carbon footprint was found since 1970. A study of Canadian beef production by Vergé et al. (2008) reported a carbon footprint of $16.6 \mathrm{~kg} \mathrm{CO}_{2} \mathrm{e} / \mathrm{kg} \mathrm{BW}$ in 1981 with a

Table 9. Environmental footprints of the beef produced at the U.S. Meat Animal Research Center using the production practices assumed for 1970 and 2005 compared to current practices

\begin{tabular}{|c|c|c|c|c|c|}
\hline \multirow[b]{2}{*}{ Foot print type } & \multicolumn{2}{|c|}{1970} & \multicolumn{2}{|c|}{2005} & \multirow{2}{*}{$\begin{array}{c}2011 \\
\text { Footprint } \\
/ \mathrm{kg} \mathrm{BW}\end{array}$} \\
\hline & $\begin{array}{c}\text { Footprint, } \\
\text { /kg BW }\end{array}$ & $\begin{array}{c}\text { Difference }^{1}, \\
\%\end{array}$ & $\begin{array}{c}\text { Footprint, } \\
\text { /kg BW }\end{array}$ & $\begin{array}{c}\text { Difference, } \\
\%\end{array}$ & \\
\hline Carbon, $\mathrm{kg} \mathrm{CO}_{2} \mathrm{e}^{2}$ & 11.63 & 6.1 & 10.87 & -0.4 & 10.92 \\
\hline Energy use, MJ & 27.17 & 0.6 & 26.67 & -1.3 & 27.00 \\
\hline Water use including precipitation, L & 22,496 & 5.1 & 21,371 & 0.1 & 21,340 \\
\hline Water use excluding precipitation, L & 1,959 & -42.4 & 2,809 & 0.7 & 2,789 \\
\hline Reactive $\mathrm{N}$ loss, g N & 94.3 & 2.8 & 83.5 & -9.8 & 91.7 \\
\hline
\end{tabular}

${ }^{1}$ Difference from 2011.

${ }^{2} \mathrm{CO}_{2} \mathrm{e}=\mathrm{CO}_{2}$ equivelant units. 
$40 \%$ improvement to $10.0 \mathrm{~kg} \mathrm{CO}_{2} \mathrm{e} / \mathrm{kg} \mathrm{BW}$ in 2006 . This major improvement was apparently due to a shift from extensive pasture production of cattle to intensive feedlot production, which does not compare to our analysis.

The energy footprint changed very little from 1970 to 2011 (Table 9), and there were offsetting effects that led to this minor difference. First, the use of smaller equipment powered primarily with gasoline engines used more fuel. On the other side, less corn production and thus less irrigation in 1970 reduced energy use. Together, these changes gave little change in energy consumption at MARC per unit of cattle BW produced.

The total water footprint in 1970 (including precipitation) was $5 \%$ greater than that of 2011, primarily because of the lower crop yields in 1970 (Table 9). With lower yields, more feed was purchased and the water footprint of that feed must be included. When precipitation was not included, the water footprint in 1970 was $42 \%$ less than the 2011 footprint, primarily because less irrigation was used in 1970. With less than half the corn land farmed in 1970, much less water was used for irrigation.

Compared to 2011, the reactive nitrogen footprint was 3\% greater in 1970, again due to offsetting effects. As shown for the 2005 scenario, not feeding distillers grain in 1970 reduced reactive nitrogen losses. Less land in corn production also reduced nitrogen losses, but the lower crop yields and the resulting increase in purchased feed increased nitrogen losses for the full system. Together, these offsetting effects lead to a relatively small reduction in the reactive nitrogen footprint from 1970 to 2011 (Table 9).

For these simulations, the factors for pre-chain resource use were not changed across the years (except for purchased feeds). Improvements in the efficiency of producing fuel, electricity, and $\mathrm{N}$ fertilizer may provide additional benefit. Considering the sensitivity values of Fig. 2, these improvements would have little impact on the carbon footprint but would provide a small reduction in the energy footprint. Improvements in water and $\mathrm{N}$ use through time were properly represented through the parameterization of the model.

The simulated change in production costs over the $40 \mathrm{yr}$ period in current dollar value was relatively small (Table 10). From 2005 to 2011, production costs decreased by $1 \%$. The major change was the increase in net feed cost due to the purchase of distillers grain. Labor and livestock maintenance costs decreased slightly because of our assumption that a greater number of animals needed to be managed in 2005 to produce the same live weight. From 1970 to 2011, there was a 6\% increase in production costs. Although the use of distillers grain increased the feed cost, this increase was more than offset by the savings obtained through increased crop yields. With fewer animals managed in 2011, labor and livestock maintenance costs were reduced. Machinery costs increased with the use of larger and more
Table 10. Production costs in current dollars for the U.S. Meat Animal Research Center using current practices and those assumed for 2005 and 1970

\begin{tabular}{|c|c|c|c|c|c|}
\hline \multirow[b]{2}{*}{ Category } & \multicolumn{2}{|c|}{1970} & \multicolumn{2}{|c|}{2005} & \multirow{2}{*}{$\begin{array}{c}2011 \\
\text { Cost, } \\
\$\end{array}$} \\
\hline & $\begin{array}{c}\text { Cost, } \\
\$\end{array}$ & $\begin{array}{c}\text { Difference }^{1}, \\
\%\end{array}$ & $\begin{array}{c}\text { Cost, } \\
\$\end{array}$ & $\begin{array}{c}\text { Difference, } \\
\%\end{array}$ & \\
\hline Machinery & $1,237,170$ & -20.6 & $1,575,541$ & 1.2 & $1,557,558$ \\
\hline Facility & 428,029 & -0.4 & 432,208 & 0.6 & 429,696 \\
\hline Energy & 477,769 & -7.1 & 524,099 & 1.9 & 514,416 \\
\hline Labor & $2,361,701$ & 9.6 & $2,205,791$ & 2.4 & $2,154,427$ \\
\hline Cropping & 550,395 & -20.2 & 712,154 & 3.2 & 689,755 \\
\hline Net feed & $1,189,693$ & 114.0 & 479,833 & -13.7 & 555,852 \\
\hline $\begin{array}{l}\text { Livestock } \\
\text { maintenance }\end{array}$ & 280,582 & 13.1 & 255,698 & 3.1 & 248,116 \\
\hline Total & $6,525,339$ & 6.1 & $6,185,324$ & 0.6 & $6,149,845$ \\
\hline Total, \$/kg BW & 2.25 & 6.6 & 2.13 & 0.9 & 2.11 \\
\hline
\end{tabular}

${ }^{1}$ Difference from 2011.

expensive equipment in 2011, which included more irrigation units. Reduced fuel use through more efficient field machinery operations was more than offset by the increased energy required for irrigation. Also, with more corn land in 2011, cropping costs increased.

These results support that some progress has been made in reducing the environmental impact of beef production at MARC over the past $40 \mathrm{yr}$. Much of this improvement is associated with increased crop yields attained through genetic improvements, particularly for corn. With greater yields, less land and fewer resource inputs are required per unit of feed produced. Genetic improvements have also been made in increasing cattle size, and this has had a modest influence on the environment. Today's cattle maintain greater rates of gain and greater finish weights, but they also eat more feed and excrete more manure than the smaller animals of the 1970s. Together, these effects can provide a reduction in the feed energy intake per unit of body weight produced, but this benefit is primarily attained through less time from birth to slaughter (Capper, 2011). In this particular operation, the age at slaughter has not changed over the $40 \mathrm{yr}$ period.

Environmental improvements made at MARC may be less than corresponding improvements made by the beef industry. As noted above, an environmental benefit for the beef industry has been an increased use of dairy calves, and this benefit is not received at MARC. The MARC production system also uses more irrigation than the overall industry, and this use has increased over the years with more corn production and some irrigation of pasture. Greater use of irrigation has increased nonprecipitation water use, energy use, and carbon emissions. These increases have offset some of the reductions attained through higher yielding crops and more efficient machinery systems.

Although the production system at MARC is similar to that of commercial beef producers, these results do not represent the industry as a whole. Beef cattle are 
produced in the United States over a wide range of climates and soil types. The range of production practices used throughout the industry influence the environmental impact of the beef produced. To better represent U.S. beef production, further analysis is needed covering all regions and the important production practices of each region across the country. The analysis procedure developed and evaluated in this study provides a methodology for broad use in determining regional and national environmental footprints of beef cattle production.

A full LCA of beef must include processing, marketing, and the consumer. The farm-gate assessment of IFSM provides the production, environmental, and economic information on cattle production needed for a full system assessment. Through our methodology, simulated production data are being used in the BASF Eco-efficiency tool (Saling et al., 2002) to more fully quantify the sustainability of beef and the historical changes that have occurred. This assessment includes social as well as environmental and economic issues of the beef industry.

\section{LITERATURE CITED}

Beauchemin, K. A., H. H. Janzen, S. M. Little, T. A. McAllister, and S. M. McGinn. 2010. Life cycle assessment of greenhouse gas emissions from beef production in western Canada: A case study. Agric. Syst. 98:67-73.

Beckett, J. L., and J. W. Oltjen. 1993. Estimation of the water requirement for beef production in the United States. J. Anim. Sci. 71:818-826.

Capper, J. L. 2011. The environmental impact of beef production in the United States: 1977 compared with 2007. J. Anim. Sci. 89:42494261.

Cundiff, L. V., K. E. Gregory, and R. M. Koch. 1984. Cattle germplasm evaluation program; Progress report no. 11. USDA, Agricultural Research Service, Clay Center, NE. www.ars.usda.gov/SP2UserFiles/ Place/54380000/GPE/GPE11.pdf. (Accessed 13 December 2012.)

International Panel on Climate Change (IPCC). 2006. Guidelines for national greenhouse inventories. Vol. 4: Agriculture, forestry and other land use, chapter 10. www.ipcc-nggip.iges.or.jp/public/2006gl/vol4. html. (Accessed 13 June 2013.)

Johnson, D. E., H. W. Phetteplace, A. F. Seidl, U. A. Schneider, and A. B. McCarl. 2003. Management variations for U.S. beef production systems: Effects on greenhouse gas emissions and profitability. 3rd International Methane and Nitrous Oxide Mitigation Conference, Beijing, China. p. 953-961.

Mekonnen, M. M., and A. Y. Hoekstra. 2010. The green, blue and grey water footprint of farm animals and animal products. Value of Water Research Report Series No. 48. Institute for Water Education, Delft, The Netherlands. www.waterfootprint.org/Reports/Report-48-WaterFootprint-AnimalProducts-Vol1.pdf. (Accessed 13 December 2012.)

Mills, J. A. N., E. Kebreab, C. M. Yates, L. A. Crompton, S. B. Cammell, M. S. Dhanoa, R. E. Agnew, and J. France. 2003. Alternative approaches to predicting methane emissions from dairy cows. J. Anim. Sci. 81:3141-3150.

National Agricultural Statistics Service (NASS). 2012. Quick Stats. http://quickstats.nass.usda.gov/(Accessed 13 December 2012.)
Pelletier, N., R. Pirog, and R. Rasmussen. 2010. Comparative life cycle environmental impacts of three beef production strategies in the upper midwestern United States. Agric. Syst. 103:380-389.

Ridoutt, B. G., P. Sanguansri, and G. S. Harper. 2011. Comparing carbon and water footprints for beef cattle production in southern Australia. Sustainability 3:2443-2455.

Rotz, C. A., D. R. Buckmaster, and J. W. Comerford. 2005. A beef herd model for simulating feed intake, animal performance, and manure excretion in farm systems. J. Anim. Sci. 83:231-242.

Rotz, C. A., M. S. Corson, D. S. Chianese, F. Montes, S. D. Hafner, and C. U. Coiner. 2012. Integrated farm system model: Reference manual. USDA Agricultural Research Service, University Park, PA. www. ars.usda.gov/SP2UserFiles/Place/19020000/ifsmreference.pdf. (Accessed 19 March 2013.)

Rotz, C. A., F. Montes, and D. S. Chianese. 2010. The carbon footprint of dairy production systems through partial life cycle assessment. J. Dairy Sci. 93:1266-1282.

Rotz, C. A., J. Oenema, and H. van Keulen. 2006. Whole farm management to reduce nitrogen losses from dairy farms: A simulation study. Appl. Eng. Agric. 22(5):773-784.

Saling, P., A. Kicherer, B. Dittrich-Kramer, R. Wittlinger, W. Zombik, I. Schmidt, W. Schrott, and S. Schmidt. 2002. Eco-efficiency analysis by BASF: The method. Int. J. Life Cycle Assess. 7(4):203-218.

Smith, G. M., D. B. Laster, L. V. Cundiff, and K. E. Gregory. 1976. Characterization of biological types of cattle II. Postweaning growth and feed efficiency of steers. J. Anim. Sci. 43:37-47.

Stackhouse-Lawson, K. R., C. A. Rotz, J. W. Oltjen, and F. M. Mitloehner. 2012. Carbon footprint and ammonia emissions of California beef production systems. J. Anim. Sci. 90:4641-4655.

Steinfeld, H., P. Gerber, T. Wassenaar, V. Castel, M. Rosales, and C. de Haan. 2006. Livestock's long shadow - Environmental issues and options. Food and Agriculture Organization of the United Nations, Rome, Italy.

Thoma, G., R. E. Martin, D. Nutter, R. Ulrich, C. Maxwell, J. Frank, and C. East. 2011. National life cycle carbon footprint study for production of U.S. swine. Final report to the National Pork Board. www.pork. org/filelibrary/NPB\%20Scan\%20Final\%20-\%20May\%202011.pdf. (Accessed 13 December 2012.)

USDA Economic Research Service (USDA-ERS). 2011. Fertilizer use and price. USDA Economic Research Service, Washington, DC. www.ers.usda.gov/data-products/fertilizer-use-and-price.aspx. (Accessed 13 December 2012.)

USDA Economic Research Service (USDA-ERS). 2012. Quarterly red meat, poultry, and egg supply and disappearance and per capita disappearance: Beef. USDA Economic Research Service, Washington, DC. www.ers.usda.gov/data-products/livestock-meat-domestic-data. aspx\#26091. (Accessed 14 December 2012.)

U.S. Environmental Protection Agency (USEPA). 2012. Inventory of U.S. greenhouse gas emissions and sinks: 1990-2010. U.S. Environmental Protection Agency, Washington, DC. www.epa.gov/climatechange/ghgemissions/usinventoryreport.html. (Accessed 3 January 2013.)

Vergé, X. P. C., J. A. Dyer, R. L. Desjardins, and D. Worth. 2008. Greenhouse gas emissions from the Canadian beef industry. Agric. Syst. 98:126-134.

Veysset, P., M. Lherm, and D. Bebin. 2010. Energy consumption, greenhouse gas emissions, and economic performance analysis in French Charolais suckler cattle farms: Model-based analysis and forecasts. Agric. Syst. 103:41-50.

Wang, M. 2012. The greenhouse gases, regulated emissions and energy use in transportation model (GREET). Argonne National Laboratory, Argonne, IL. http://greet.es.anl.gov/. (Accessed 7 December 2012.) 